Crop Breeding and Applied Biotechnology 15: 218-226, 2015

Brazilian Society of Plant Breeding. Printed in Brazil

\title{
ARTICLE
}

http://dx.doi.org/10.1590/1984-70332015v15n4a38

\section{Genetic progress and potential of common bean families obtained by recurrent selection}

Anatércia Ferreira Alves ${ }^{1 *}$, José Ângelo Nogueira de Menezes Júnior ${ }^{2}$, Vanessa Maria Pereira Silva Menezes ${ }^{1}$, José Eustáquio de Souza Carneiro ${ }^{1}$, Pedro Crescêncio Souza Carneiro ${ }^{1}$ and Andrea Ferreira Alves ${ }^{3}$

Received 28 January 2014

Accepted 12 August 2015

\begin{abstract}
The objective of this study was to estimate the genetic gain of two recurrent selection cycles in common bean breeding and identify families with the potential to generate superior lines. The base population, cycle zero $\left(C_{n}\right)$, was obtained by combining 20 carioca bean parents, populations with favorable phenotypes for several agronomically important traits. The parents were recombined in a circulant diallel scheme, in which each parent participated in two crosses, generating 20 populations. From these populations, families were derived and evaluated for three seasons in the generations $F_{2: 3} F_{2: 4}$ and $F_{2: 5^{\circ}}$. The same procedures of recombination and evaluation in $C_{0}$ were performed in cycle one $\left(C_{1}\right)$. The genetic gain for yield, estimated from the simultaneous evaluation of the 40 best families of each cycle, was $8.6 \%$. Families with potential to generate superior lines to cultivar Pérola were identified, especially among the $C_{I}$ families.
\end{abstract}

Key words: Phaseolus vulgaris, genetic gain, common bean breeding.

\section{INTRODUCTION}

In Brazil, different types of common bean are grown, and the groups with carioca, black, red, purple, pinkish, and Manteigão grain are the best known. Regionally, the population has a preference for one or the other of these types. However, the common bean type with the greatest acreage and highest consumption in Brazil is the carioca bean (beige with light brown stripes), which is why the main bean breeding programs in Brazil have focused on breeding this grain type.

In breeding programs, several strategies can be applied and produce satisfactory results. Of these, hybridization has become a routine practice in modern breeding programs and the main source of new common bean lines (Couto et al. 2008, Rocha et al. 2012, Menezes Júnior et al. 2013). The great difficulty in plant breeding is to find two parents that combine all phenotypes of interest in a single plant. Thus, the alternative would be multiple crosses. However, there are restrictions to the use of this strategy (Carneiro et al. 2002), since the greater the number of parents involved in obtaining the segregating population, the greater is the number of necessary cycles of crosses, and the greater must be the size of this population.

Therefore, it is not always possible to associate the phenotypes of interest at the desired intensity in a single plant, to solve all problems at once. This shows that breeding should be carried out in stages. In this case, an alternative would be recurrent selection, i.e., successive cycles of selection and intercrossing of the best plants or the best families (Geraldi 1997).

The efficiency of recurrent selection in breeding autogamous plants, especially for common bean, was demonstrated for several traits (Sing et al. 1999, Garcia et al. 2003, Menezes Júnior et al. 2008, Arantes et al. 2010). Silva et al. (2010) confirmed the efficiency of this strategy in breeding of common bean with carioca grain. The authors observed an increase in yield and improved grain appearance, with variability in the population, even after eight selection cycles.

Some variations are observed when the methodology of recurrent selection is used in autogamous plants, mainly in

\footnotetext{
${ }^{1}$ Universidade Federal de Viçosa, Departamento de Fitotecnia, Av. P.H. Rolfs, s/n, 36.571-900, Viçosa, MG, Brazil. *E-mail: anaterciaa@yahoo.com.br

${ }^{2}$ Empresa Brasileira de Pesquisa Agropecuária. Embrapa Agrossilvipastoril, 78.550970, Sinop, MT, Brazil

${ }^{3}$ Universidade Federal do Ceará, Departamento de Fitotecnia, Av. Mister Hull, s/n, Campus do Pici, 60.455-900, Fortaleza, CE, Brazil
} 
terms of the selection unit, the number of parents, the way the intercrosses are preformed, evaluation method of the obtained populations and the method of estimating genetic gain. The periodic estimation of genetic gain is essential for decision-making with regard to selection strategies used and possible alternatives to increase selection efficiency.

In autogamous plants, the mean of a population derived from intercrossing will change after each selfing, due to the presence of dominance. Thus, the procedures commonly used to compare selection cycles are assessments of families or lines of the different cycles, which can be done using standard controls (Arantes et al. 2010) or the simultaneous assessment of the best families or lines of each cycle (Ramalho et al. 2005, Menezes Júnior et al. 2013).

The objectives of this study were to estimate the genetic gain of two recurrent selection cycles in breeding of common bean with carioca grain and identify families with superior capacity to breed superior lines.

\section{MATERIAL AND METHODS}

The experiments were conducted at the Experimental Station of Coimbra, of the Department of Plant Science, of the Federal University of Viçosa (UFV), in the municipality of Coimbra (lat $20^{\circ} 50^{\prime} 30^{\prime} \mathrm{S}$, long $42^{\circ} 48^{\prime} 30^{\prime \prime} \mathrm{W}$ and alt $720 \mathrm{~m}$ asl), in the dry season and winter of 2007, 2008, 2010, and 2011, and in the rainy season of 2011. Fertilization and cultivation were carried out as officially recommended for common bean in the region.

The base population, cycle zero $\left(\mathrm{C}_{0}\right)$ was obtained by combining 20 parents with carioca grain in a circulant diallel scheme, with each parent participating in two crosses (Table 1). Thus, 20 populations were generated from simple crosses. The population of cycle one $\left(\mathrm{C}_{\mathrm{T}}\right)$ was obtained by recombining the best 20 families of $\mathrm{C}_{0}$ (Table 1 ) in the same mating scheme, resulting in 20 new populations. From the populations of both cycles, families were derived and evaluated for three seasons in different generations $\left(\mathrm{F}_{2: 3}\right.$, $\mathrm{F}_{2: 4}$ and $\mathrm{F}_{2: 5}$ ).

From each $\mathrm{F}_{2}$ population in $\mathrm{C}_{0}$ and $\mathrm{C}_{\mathrm{I}} 19$ families were derived and evaluated in the winter of $2007\left(\mathrm{C}_{0}\right)$ and winter of $2010\left(C_{\mathrm{I}}\right)$. Each experiment consisted of 400 treatments and $380 \mathrm{~F}_{2: 3}$ families and 20 controls, represented by commercial cultivars, elite lines and some of the parents used in the composition of the base population. A lattice square design of $20 \times 20$, with two replications and plots of two $1-\mathrm{m}$ rows was used. The traits yield and grain appearance, rust severity, and plant architecture were evaluated.

Of the $380 \mathrm{~F}_{2: 3}$ families of each cycle, the best 160 were selected, based on yield and grain appearance. In the following generation $\left(\mathrm{F}_{2: 4}\right)$, dry season of $2008\left(\mathrm{C}_{0}\right)$ and dry season of $2011\left(\mathrm{C}_{\mathrm{T}}\right)$, the 160 selected families along with nine controls (BRSMG Pioneiro, Ouro Negro, BRSMG Talismã, Pérola, Requinte, BRSMG Majestoso, VC6, BRSMG Madrepérola, and Horizonte) were evaluated in a randomized lattice square $(13 \times 13)$ three times, on plots of two 2-m rows. In these seasons, yield and grain appearance, plant architecture and angular leaf spot severity were evaluated. Using the 169 common treatments of the two generations $\left(\mathrm{F}_{2: 3}\right.$ and $\left.\mathrm{F}_{2: 4}\right)$, a combined analysis of these generations was carried out for each cycle $\left(\mathrm{C}_{0}\right.$ and $\left.\mathrm{C}_{\mathrm{I}}\right)$. The best 40 families of each cycle were selected and stored in a refrigerator to estimate the genetic gain later.

The severity of rust and angular leaf spot, plant architecture and grain appearance were evaluated on scales. Rust severity was evaluated on a 1-6 scale (Stavely et al. 1983), where 1 indicated no visible pustules (immune) and 6 , severe disease symptoms, resulting in premature leaf fall. For angular leaf spot, disease severity was assessed by a 1-9 scale, proposed by Van Schoonhoven and Pastor-Corrales (1987), where grade 1 represented plants without disease symptoms and 9 , severe disease symptoms, resulting in premature leaf drop. For plant architecture, we used a 1 - 5

Table 1. Mating scheme to establish cycle zero $\left(\mathrm{C}_{0}\right)$ and cycle one $\left(\mathrm{C}_{\mathrm{I}}\right)$

\begin{tabular}{|c|c|c|c|c|}
\hline \multicolumn{5}{|c|}{ Intercross of 20 parents (base population- $\mathrm{C}_{0}$ ) } \\
\hline $1 \times 6$ & $5 \times 10$ & $9 \times 14$ & $13 \times 18$ & $17 \times 2$ \\
\hline $2 \times 7$ & $6 \times 11$ & $10 \times 15$ & $14 \times 19$ & $18 \times 3$ \\
\hline $3 \times 8$ & $7 \times 12$ & $11 \times 16$ & $15 \times 20$ & $19 \times 4$ \\
\hline $4 \times 9$ & $8 \times 13$ & $12 \times 17$ & $16 \times 1$ & $20 \times 5$ \\
\hline \multicolumn{5}{|c|}{ Intercross of the 20 families selected in cycle zero (population of cycle one $-C_{T}$ ) } \\
\hline$(1.6) \times(9.14)$ & $(6.11) \times(14.19)$ & & & $(16.1) \times(4.9)$ \\
\hline$(4.9) \times(12.17)$ & $(9.14) \times(17.2)$ & & & $(7.12) \times(19.4)$ \\
\hline$(5.10) \times(13.18)$ & $(10.15) \times(18.3)$ & & & $(8.13) \times(20.5)$ \\
\hline
\end{tabular}


scale similar to that proposed by Collicchio et al. (1997), where 1 are completely erect plants and 5, prostrate plants. For grain appearance we also used a 1-5 scale, proposed by Ramalho et al. (1998), where grade 1 is assigned to the typical carioca grain pattern.

In every generation, the data were analyzed separately, considering the effects of treatments and the mean as fixed, according to the model $Y_{i j l}=m+t_{i}+b_{j}+P_{l(j)}+e_{i j l}$, where: $Y_{i j l}$ is the observed value in the plot under treatment $i, l$ in block $l$ within the replication $j ; m$ is the overall mean of the experiment; $t_{i}$ effect of treatment $i$, where $(i=1,2, \ldots, n) ; b j$ effect of replication $j$, where $j=1$ and 2 in $\mathrm{F}_{2: 3}$ and $j=1$, 2 and 3 in the other generations; $P_{l(j)}$ the effect of block $l$ within replication $j$, where $l=1,23, \ldots . n ; e_{i j l}$ the experimental error associated with observation $Y_{i j l}$, assuming that the errors are independent and normally distributed with zero mean and variance $\sigma^{2}$.

The model adopted in the combined analysis was $Y_{i j k}=$ $m+t_{i}+b_{j(k)}+a_{k}+(t a)_{j k}+e_{i j k}$, where: $Y_{i j}$ is the observed value in the plot receiving treatment $i$ in replication $j$ in generation $k ; m$ is the overall mean of the experiment; $t_{i}$ the effect of treatment $i$, where $(i=1,2, \ldots, n) ; b_{j(k)}$ effect of replication $j$ within generating $k$, where $j=1,2$ and $3 ; a_{k}$ the effect of generation $k$, where $k=1,2 ;(t a)_{i k}$ the interaction effect between treatment $i$ and generation $k$; $\bar{e}_{i j k}$ the mean error associated with observation $Y_{i j k}$, assuming that the errors are independent and normally distributed, with zero mean and variance $\sigma^{2}$.
The genetic gain was estimated by comparing the 40 best families obtained in each cycle $\left(\mathrm{C}_{0}\right.$ and $\left.\mathrm{C}_{\mathrm{I}}\right)$ simultaneously. The experiments were conducted in the winter and rainy season of 2011, in a randomized block design with three replications and plots with two $2-$ m rows. The same controls were used as in $\mathrm{F}_{2: 4^{4}}$. The following traits were evaluated in both seasons: grain yield, plant architecture and severity of angular leaf spot and rust, whereas grain appearance was assessed in the winter only. The genetic gain (GG) was estimated from the following expression:

$$
\operatorname{PG}(\%)=\left(\frac{\bar{X}_{C_{I}}-\bar{X}_{C_{0}}}{\bar{X}_{C_{0}}}\right) x 100,
$$

where: $\bar{X}_{C 1}$ is the mean of the 40 families of cycle one $\left(\mathrm{C}_{\mathrm{I}}\right)$ and $\bar{X}_{C 0}$ is the mean of the 40 families of cycle zero $\left(\mathrm{C}_{0}\right)$.

\section{RESULTS AND DISCUSSION}

The summary of the combined variance analysis of the assessment of the 160 common families in $\mathrm{F}_{2: 3}$ and $\mathrm{F}_{2: 4}$ of $\mathrm{C}_{0}$ and $\mathrm{C}_{\mathrm{I}}$ is represented in Table 2. There was a significant effect for the family source of variation (F) in both cycles, indicating variability in the population for grain yield, plant architecture and grain appearance. The family means for yield, grain appearance and plant architecture were higher than those of the controls. The family $\mathrm{x}$ season interaction was significant in both cycles, indicating inconsistency in family performance in the test environments. This significant family $\mathrm{x}$ season interaction in common bean was frequently observed elsewhere

Table 2. Summary of the combined analyses of variance of grain yield $\left(\mathrm{kg} \mathrm{ha}^{-1}\right)$ and grain appearance, based on the evaluation of the $\mathrm{F}_{2: 3}$ and $\mathrm{F}_{2: 4}$ families of $\mathrm{C}_{0}$, winter 2007 and dry season 2008 , and of grain yield $\left(\mathrm{kg} \mathrm{ha}^{-1}\right)$, grain appearance and plant architecture, based on the evaluation of the $\mathrm{F}_{2: 3}$ and $\mathrm{F}_{2: 4}$ families of $\mathrm{C}_{\mathrm{I}}$, winter 2010 and dry season 2011

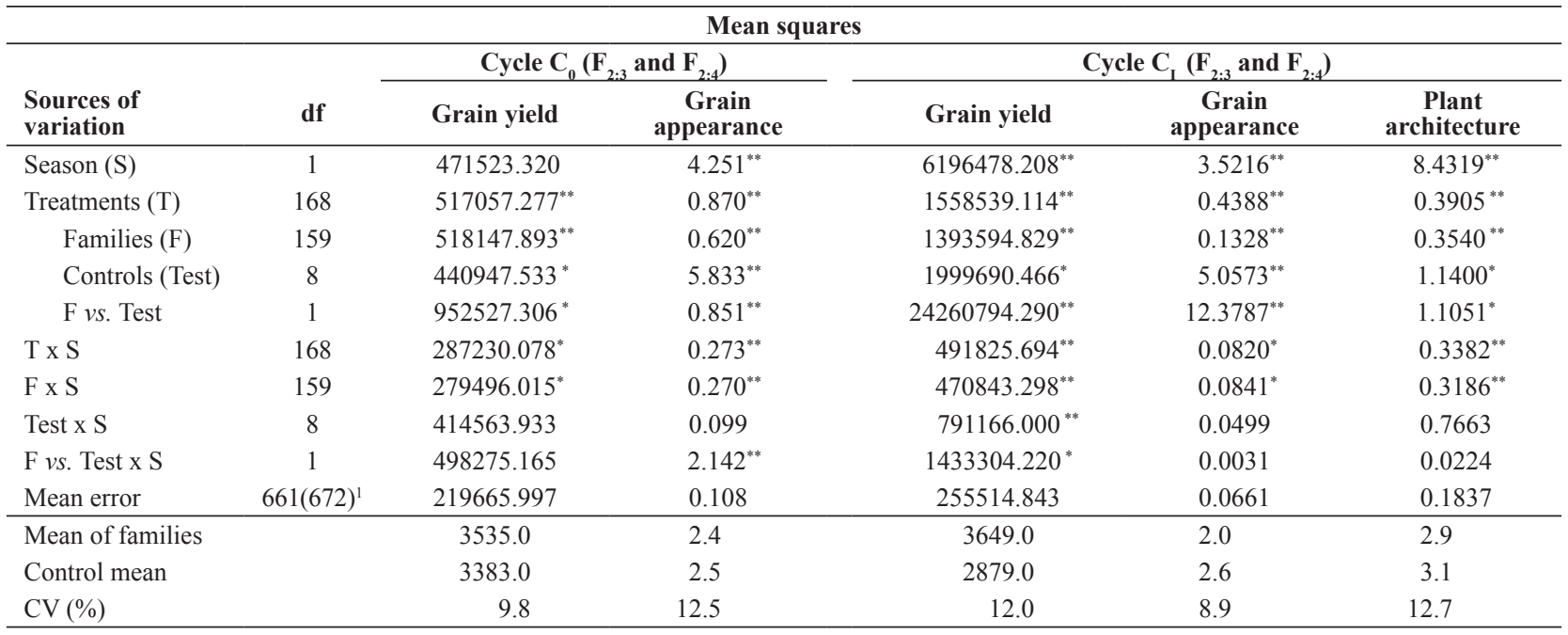

"* and "Significant at $1 \%$ and $5 \%$ probability, respectively, by the $\mathrm{F}$ test; ${ }^{1}$ Value in parentheses indicates the number of degrees of freedom for grain appearance. 
(Arantes et al. 2010, Menezes Júnior et al. 2013).

The mean yield, grain appearance, plant architecture, and severity of rust and angular leaf spot of the 40 best families of each cycle, selected based on the results of yield and grain appearance of the combined analysis of $\mathrm{F}_{2: 3}$ and $\mathrm{F}_{2: 4}$ generations, are listed in Tables 3 and 4 . The $\mathrm{C}_{0}$ families had a similar performance to cultivar Pérola for yield, grain appearance, plant architecture, and angular leaf spot severity.

Table 3. Means of grain yield $\left(\mathrm{kg} \mathrm{ha}^{-1}\right)$, grain appearance, plant architecture and rust severity (RU) and of angular leaf spot (LS) das 40 best families in $\mathrm{C}_{0}$, evaluated in the generations $\mathrm{F}_{2: 3}$ and $\mathrm{F}_{2: 4}$, winter 2007 and dry season in 2008

\begin{tabular}{|c|c|c|c|c|c|}
\hline Families & Yield 2007/2008 & $\begin{array}{c}\text { Grain appearance } \\
2007 / 2008\end{array}$ & $\begin{array}{c}\text { Plant architecture } \\
2008\end{array}$ & Severity of RU 2007 & Severity of LS 2008 \\
\hline 2 & 3439 a b c & $2.3 \mathrm{abc}$ & $3.7 \mathrm{a} \mathrm{b} \mathrm{c}$ & $1.1 \mathrm{~b} \mathrm{c}$ & $4.1 \mathrm{a} \mathrm{b} \mathrm{c}$ \\
\hline 4 & $3516 \mathrm{abc}$ & $2.3 \mathrm{abc}$ & $3.4 \mathrm{a} \mathrm{b} \mathrm{c}$ & $1.5 \mathrm{~b} \mathrm{c}$ & $3.9 \mathrm{a} \mathrm{bc}$ \\
\hline 5 & $3880 \mathrm{abc}$ & $2.1 \mathrm{abc}$ & $2.7 \mathrm{ab}$ & $2.5 \mathrm{~b} \mathrm{c}$ & $3.6 \mathrm{abc}$ \\
\hline 6 & $3849 \mathrm{a} \mathrm{b} \mathrm{c}$ & $2.3 \mathrm{abc}$ & $3.2 \mathrm{abc}$ & $2.4 \mathrm{bc}$ & $3.4 \mathrm{a} \mathrm{b} \mathrm{c}$ \\
\hline 8 & $3515 \mathrm{abc}$ & $2.3 \mathrm{abc}$ & $3.0 \mathrm{abc}$ & $1.3 \mathrm{~b} \mathrm{c}$ & $5.2 \mathrm{abc}$ \\
\hline 9 & $3663 \mathrm{abc}$ & $2.5 \mathrm{ab}$ & $3.0 \mathrm{a} \mathrm{b} \mathrm{c}$ & $1.1 \mathrm{~b} \mathrm{c}$ & $3.1 \mathrm{abc}$ \\
\hline 10 & $3734 \mathrm{abc}$ & $2.0 \mathrm{abc}$ & $3.4 \mathrm{a} \mathrm{b} \mathrm{c}$ & $1.0 \mathrm{~b} \mathrm{c}$ & $5.5 \mathrm{abc}$ \\
\hline 11 & $4260 \mathrm{abc}$ & $2.4 \mathrm{ab}$ & $3.9 \mathrm{abc}$ & $1.9 \mathrm{~b} \mathrm{c}$ & $5.2 \mathrm{abc}$ \\
\hline 12 & $3272 \mathrm{abc}$ & $2.1 \mathrm{a} \mathrm{b} \mathrm{c}$ & $3.7 \mathrm{a} \mathrm{b} \mathrm{c}$ & $1.5 \mathrm{~b} \mathrm{c}$ & $4.4 \mathrm{a} \mathrm{b} \mathrm{c}$ \\
\hline 17 & 3939 a b c & $2.5 \mathrm{ab}$ & $3.7 \mathrm{a} \mathrm{b} \mathrm{c}$ & $2.5 \mathrm{~b} \mathrm{c}$ & $4.5 \mathrm{abc}$ \\
\hline 18 & $3699 \mathrm{abc}$ & $2.4 \mathrm{ab}$ & $3.2 \mathrm{abc}$ & $1.8 \mathrm{~b} \mathrm{c}$ & $6.0 \mathrm{a} \mathrm{b} \mathrm{c}$ \\
\hline 19 & $3797 \mathrm{a} \mathrm{b} \mathrm{c}$ & $2.3 \mathrm{abc}$ & $3.2 \mathrm{abc}$ & $2.0 \mathrm{~b} \mathrm{c}$ & $4.8 \mathrm{abc}$ \\
\hline 20 & $3552 \mathrm{abc}$ & $2.2 \mathrm{abc}$ & $3.8 \mathrm{a} \mathrm{b} \mathrm{c}$ & $1.0 \mathrm{~b} \mathrm{c}$ & $4.3 \mathrm{a} \mathrm{b} \mathrm{c}$ \\
\hline 21 & $3572 \mathrm{abc}$ & $2.2 \mathrm{abc}$ & $3.1 \mathrm{abc}$ & $1.6 \mathrm{bc}$ & $4.0 \mathrm{a} \mathrm{b} \mathrm{c}$ \\
\hline 22 & $3650 \mathrm{abc}$ & $2.3 \mathrm{abc}$ & $3.4 \mathrm{a} \mathrm{b} \mathrm{c}$ & $1.5 \mathrm{~b} \mathrm{c}$ & $3.3 \mathrm{abc}$ \\
\hline 23 & $4297 \mathrm{a} \mathrm{b} \mathrm{c}$ & $2.4 \mathrm{a} \mathrm{b}$ & $3.8 \mathrm{a} \mathrm{b} \mathrm{c}$ & $1.5 \mathrm{~b} \mathrm{c}$ & $5.0 \mathrm{abc}$ \\
\hline 24 & $3913 \mathrm{abc}$ & $2.3 \mathrm{abc}$ & $3.2 \mathrm{abc}$ & $1.5 \mathrm{bc}$ & $3.5 \mathrm{abc}$ \\
\hline 25 & $3641 \mathrm{a} \mathrm{b} \mathrm{c}$ & $2.1 \mathrm{a} \mathrm{b} \mathrm{c}$ & $3.3 \mathrm{a} \mathrm{b} \mathrm{c}$ & $1.5 \mathrm{~b} \mathrm{c}$ & $3.7 \mathrm{abc}$ \\
\hline 26 & $3667 \mathrm{abc}$ & $2.1 \mathrm{abc}$ & $3.3 \mathrm{abc}$ & $2.0 \mathrm{~b} \mathrm{c}$ & $3.7 \mathrm{abc}$ \\
\hline 34 & $4298 \mathrm{a} \mathrm{b} \mathrm{c}$ & $1.9 \mathrm{a} \mathrm{b} \mathrm{c}$ & $4.0 \mathrm{abc}$ & $2.1 \mathrm{~b} \mathrm{c}$ & $5.6 \mathrm{abc}$ \\
\hline 35 & 3926 a b c & $2.3 \mathrm{abc}$ & $2.8 \mathrm{ab}$ & $2.5 \mathrm{~b} \mathrm{c}$ & $4.9 \mathrm{a} \mathrm{b} \mathrm{c}$ \\
\hline 36 & $3794 \mathrm{a} \mathrm{b} \mathrm{c}$ & $2.1 \mathrm{abc}$ & $3.7 \mathrm{abc}$ & $1.1 \mathrm{~b} \mathrm{c}$ & $4.1 \mathrm{a} \mathrm{b} \mathrm{c}$ \\
\hline 37 & $3649 \mathrm{a} \mathrm{b} \mathrm{c}$ & $2.2 \mathrm{abc}$ & $3.6 \mathrm{abc}$ & $3.0 \mathrm{a} \mathrm{c}$ & $3.4 \mathrm{a} \mathrm{b} \mathrm{c}$ \\
\hline 38 & 3996 a b c & $2.9 \mathrm{ab}$ & $3.4 \mathrm{a} \mathrm{b} \mathrm{c}$ & $1.6 \mathrm{~b} \mathrm{c}$ & $4.8 \mathrm{abc}$ \\
\hline 39 & $3976 \mathrm{abc}$ & $2.2 \mathrm{abc}$ & $3.1 \mathrm{abc}$ & $1.0 \mathrm{~b} \mathrm{c}$ & $4.8 \mathrm{a} \mathrm{b} \mathrm{c}$ \\
\hline 40 & $3947 \mathrm{a} \mathrm{b} \mathrm{c}$ & $2.4 \mathrm{ab}$ & $3.7 \mathrm{a} \mathrm{b} \mathrm{c}$ & $1.0 \mathrm{~b} \mathrm{c}$ & $5.5 \mathrm{abc}$ \\
\hline Pérola & $3733 \mathrm{a}$ & $2.2 \mathrm{a}$ & $3.3 \mathrm{a}$ & $4.6 \mathrm{a}$ & $5.0 \mathrm{a}$ \\
\hline BRSMG Majestoso & $3290 \quad b$ & $2.2 \mathrm{~b}$ & $3.2 \mathrm{~b}$ & $1.1 \mathrm{~b}$ & $3.8 \mathrm{~b}$ \\
\hline BRSMG Madrepérola & $3534 \quad \mathrm{c}$ & $1.5 \mathrm{c}$ & 3.8 & $1.6 \mathrm{c}$ & $4.3 \quad \mathrm{c}$ \\
\hline
\end{tabular}

*Means followed by the letters a, b and c, in a column, did not differ, respectively, from the controls Pérola, BRSMG Majestoso, and BRSMG Madrepérola, by the Dunnett test at $5 \%$ probability. 
AF Alves et al.

For rust severity, 39 families (97.5\%) performed better than cultivar Pérola, indicating a satisfactory resistance level in the population (Table 3).

In $\mathrm{C}_{\mathrm{I}}$, nine families exceeded the yield of cultivar
Pérola, and all were similar in grain appearance and plant architecture (Table 4). For rust severity, 20 families (50\%) were superior to cultivar Pérola, indicating higher rust incidence in the $\mathrm{C}_{\mathrm{I}}$ than in the $\mathrm{C}_{0}$ population. However, in general, all families had satisfactory levels of rust resistance.

Table 4. Means of grain yield $\left(\mathrm{kg} \mathrm{ha}^{-1}\right)$, grain appearance, plant architecture and rust severity, of the 40 best families, evaluated in the generations $\mathrm{F}_{2: 3}$ and $\mathrm{F}_{2: 4}$ in $\mathrm{C}_{\mathrm{I}}$, in the winter of 2010 and 2011

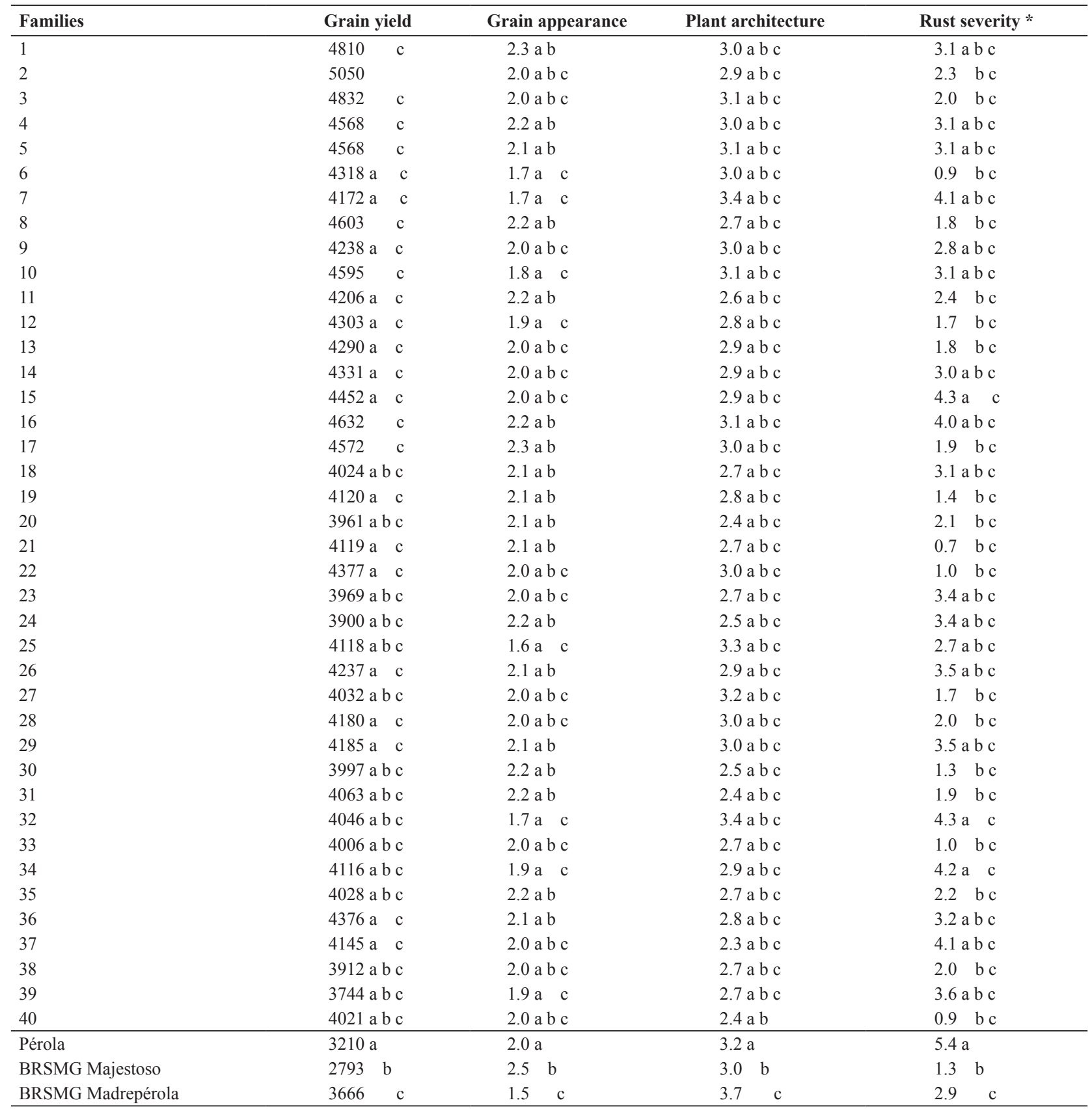

*Means followed by the letters a, b and c, in a column, did not differ, respectively, from the controls Pérola, BRSMG Majestoso, and BRSMG Madrepérola, by the Dunnett test at $5 \%$ probability. 
Since the evaluations were carried out in different years, different races of the highly variable pathogen may have occurred (Souza et al. 2005). Cultivar Pérola, the most widely grown in Brazil, is a reference for yield and grain appearance, demonstrating the promising potential of families to breed lines with carioca grain.

Table 5 is a summary of the combined variance analysis regarding the simultaneous evaluation of the 40 best families of each cycle in the winter and rainy season of 2011. The families differed significantly for all traits. The $\mathrm{C}_{0}$ families also differed significantly for the characteristics. For the $\mathrm{C}_{\mathrm{I}}$ families, there was no significant difference in plant architecture and rust severity. The family x season interaction was significant for severity of angular leaf spot and rust. For grain yield and plant architecture, the family $\mathrm{x}$ season interaction was not significant, indicating that for these traits, the performance of the families was consistent in the different environments.

The $\mathrm{C}_{\mathrm{I}}$ families had higher mean grain yield than the $\mathrm{C}_{0}$ families (Table 5). The significant effect in the comparison of $\mathrm{FC}_{0}$ with $\mathrm{FC}_{1}$ indicated genetic gain for grain yield. The means of the 20 highest-yielding families of the simultaneous evaluation of $\mathrm{C}_{0}$ and $\mathrm{C}_{\mathrm{I}}$ cycles, of grain yield, grain appearance, plant architecture and severity of rust and angular leaf spot are presented in Table 6 . The performance of these families was similar to that of the controls Pérola, BRSMG Majestoso and BRSMG Madrepérola in grain yield, plant architecture and resistance to angular leaf spot. In terms of grain appearance, two families were superior to cultivar Pérola, both in $\mathrm{C}_{\mathrm{I}}$.

The genetic gain for grain yield was $9 \%$ and $8 \%$ in the winter and rainy season 2011, respectively (Table 7). In the mean of the two seasons, the genetic gain was $8.6 \%$, which is equivalent to $293 \mathrm{~kg} \mathrm{ha}^{-1}$. Genetic gain estimates of recurrent selection in common bean for grain yield from 3.3 to $55 \%$ are reported in the literature (Ranalli 1996, Singh et al. 1999, Ramalho et al. 2005, Menezes Júnior et al. 2008, Silva et al. 2010). Ramalho et al. (2005) evaluated the genetic gain in four recurrent selection cycles in breeding of carioca bean in grain yield and appearance. To this end, they evaluated the five best lines of each cycle in two seasons (winter and rainy). The yield gains were $7.2 \%$ in winter and $4.3 \%$ in the rainy season.

In this study, although there were no gains for grain appearance and rust resistance, the grades in all families selected in $\mathrm{C}_{0}$ and $\mathrm{C}_{\mathrm{I}}$ were less than or equal to 2.5 , however promising from the point of view of grain appearance and rust resistance. This indicates that the population has a

Table 5. Summary of the combined analyses of variance of grain yield $\left(\mathrm{kg} \mathrm{ha}^{-1}\right)$, plant architecture and severity of angular leaf spot (LS) and rust (RU), based on the evaluation of the best $\mathrm{F}_{2: 6}$ families of $\mathrm{C}_{0}$ and $\mathrm{C}_{\mathrm{I}}$ evaluated simultaneously in the winter and rainy seasons of 2011

\begin{tabular}{|c|c|c|c|c|c|}
\hline \multirow[b]{2}{*}{ Source of variation } & \multirow[b]{2}{*}{ df } & \multicolumn{4}{|c|}{ Mean squares } \\
\hline & & Grain yield & Plant architecture & Severity of LS & Severity of RU \\
\hline Harvest (S) & 1 & $315717875.400 * *$ & $4.6817 * *$ & $883.8371^{* *}$ & $128.5468^{* *}$ \\
\hline Treatments (T) & 88 & $1105559.131^{* *}$ & $0.1745^{*}$ & $3.3492 * *$ & $1.2555^{* *}$ \\
\hline Families (F) & 79 & $950537.015 * *$ & $0.1542 * *$ & $3.3163 * *$ & $1.1768 * *$ \\
\hline Families $\mathrm{C}_{0}\left(\mathrm{FC}_{0}\right)$ & 39 & $1052000.002 * *$ & $0.2426 * *$ & $3.8252 * *$ & $1.4598 * *$ \\
\hline Families $\mathrm{C}_{\mathrm{I}}\left(\mathrm{F} \mathrm{C}_{\mathrm{I}}\right)$ & 39 & $608848.790 * *$ & 0.0694 & $2.6598 * *$ & 0.9231 \\
\hline F vs. Test & 1 & $4793878.241 *$ & $0.8408 * *$ & $3.3684 * *$ & $0.9238^{*}$ \\
\hline $\mathrm{T} \times \mathrm{S}$ & 88 & $427336.000 *$ & 0.1031 & $1.9015 * *$ & 0.3764 \\
\hline $\mathrm{F} \times \mathrm{S}$ & 79 & 411476.864 & 0.0748 & $1.7594 * *$ & $0.3071 *$ \\
\hline $\mathrm{FC}_{0} \times \mathrm{S}$ & 39 & 411994.613 & 0.0658 & $1.7056^{* *}$ & 0.3124 \\
\hline $\mathrm{FC}_{\mathrm{I}} \times \mathrm{S}$ & 39 & 426098.285 & 0.0849 & $1.6837 * *$ & 0.3204 \\
\hline Mean error & 352 & 324249.126 & 0.0996 & 0.4262 & 0.2275 \\
\hline Family mean $\mathrm{C}_{0}$ & & 3404.0 & 2.5 & 2.4 & 1.8 \\
\hline Family mean $C_{I}$ & & 3697.0 & 2.5 & 2.6 & 1.8 \\
\hline Control mean & & 3236.0 & 2.6 & 2.8 & 2.0 \\
\hline $\mathrm{CV}(\%)$ & & 16.2 & 12.5 & 25.9 & 25.9 \\
\hline
\end{tabular}

"*and "Significant at $1 \%$ and $5 \%$ probability, respectively, by the $\mathrm{F}$ test. 
AF Alves et al.

Table 6. Means of grain yield $\left(\mathrm{kg} \mathrm{ha}^{-1}\right)$ and grain appearance (GA), plant architecture (ARC) and rust severity (RU) and of angular leaf spot (LS) of the 20 best $\mathrm{F}_{2: 6}$ families of $\mathrm{C}_{0}$ and $\mathrm{C}_{\mathrm{I}}$, evaluated simultaneously in the winter and rainy seasons of 2011

\begin{tabular}{|c|c|c|c|c|c|}
\hline Treatments & Yield & GA* & ARC & RU & $\mathbf{L S}$ \\
\hline $42-\mathrm{C}_{\mathrm{I}}$ & $4483 \mathrm{abc}$ & $2.0 \mathrm{ab}$ & $2.5 \mathrm{abc}$ & $1.8 \mathrm{bc}$ & $2.0 \mathrm{abc}$ \\
\hline $48-\mathrm{C}_{\mathrm{I}}$ & $4189 \mathrm{abc}$ & $2.5 \mathrm{ab}$ & $2.3 \mathrm{abc}$ & $1.3 \mathrm{bc}$ & $2.7 \mathrm{abc}$ \\
\hline $47-\mathrm{C}_{\mathrm{I}}$ & $4087 \mathrm{abc}$ & $2.2 \mathrm{ab}$ & $2.3 \mathrm{abc}$ & $2.5 \mathrm{ab}$ & $2.5 \mathrm{abc}$ \\
\hline $80-\mathrm{C}_{\mathrm{I}}$ & $4054 \mathrm{abc}$ & $2.0 \mathrm{ab}$ & $2.5 \mathrm{abc}$ & $1.3 \mathrm{bc}$ & $2.5 \mathrm{abc}$ \\
\hline $44-C_{I}$ & $3983 \mathrm{abc}$ & $2.5 \mathrm{ab}$ & $2.5 \mathrm{abc}$ & $1.7 \mathrm{bc}$ & $2.2 \mathrm{abc}$ \\
\hline $59-\mathrm{C}_{\mathrm{I}}$ & $3974 \mathrm{abc}$ & $2.3 \mathrm{ab}$ & $2.6 \mathrm{abc}$ & $1.3 \mathrm{bc}$ & $2.0 \mathrm{abc}$ \\
\hline $41-\mathrm{C}_{\mathrm{I}}$ & $3963 \mathrm{abc}$ & $2.5 \mathrm{ab}$ & $2.4 \mathrm{abc}$ & $1.7 \mathrm{bc}$ & $1.7 \mathrm{abc}$ \\
\hline $34-\mathrm{C}_{0}$ & $3948 \mathrm{abc}$ & $2.3 \mathrm{ab}$ & $2.3 \mathrm{abc}$ & $2.0 \mathrm{abc}$ & $2.0 \mathrm{abc}$ \\
\hline $66-\mathrm{C}_{\mathrm{I}}$ & $3945 \mathrm{abc}$ & $2.3 \mathrm{ab}$ & $2.7 \mathrm{abc}$ & $1.5 \mathrm{bc}$ & $2.2 \mathrm{abc}$ \\
\hline $39-\mathrm{C}_{0}$ & $3877 \mathrm{abc}$ & $2.3 \mathrm{ab}$ & $2.2 \mathrm{abc}$ & $1.8 \mathrm{bc}$ & $1.7 \mathrm{abc}$ \\
\hline $76-\mathrm{C}_{\mathrm{I}}$ & $3869 \mathrm{abc}$ & $2.2 \mathrm{ab}$ & $2.5 \mathrm{abc}$ & $2.2 \mathrm{abc}$ & $2.0 \mathrm{abc}$ \\
\hline $58-\mathrm{C}_{\mathrm{I}}$ & $3866 \mathrm{abc}$ & $2.2 \mathrm{ab}$ & $2.4 \mathrm{abc}$ & $1.5 \mathrm{bc}$ & $2.0 \mathrm{abc}$ \\
\hline Pérola & 3215 a & $2.5 \mathrm{a}$ & $2.4 \mathrm{a}$ & $3.0 \mathrm{a}$ & $2.2 \mathrm{a}$ \\
\hline BRSMG Majestoso & $3309 \mathrm{~b}$ & $2.5 \mathrm{~b}$ & $2.4 \quad \mathrm{~b}$ & $1.7 \mathrm{~b}$ & $3.0 \mathrm{~b}$ \\
\hline BRSMG Madrepérola & $3106 \quad \mathrm{c}$ & $1.3 \mathrm{c}$ & $2.9 \quad \mathrm{c}$ & $1.3 \mathrm{c}$ & 2.3 \\
\hline
\end{tabular}

* Means based on only one season (winter 2011). Means followed by the letters a. b and c in a column did not differ, respectively, from the controls Pérola. BRSMG Majestoso. and BRSMG Madrepérola, by the Dunnett test at $5 \%$ probability.

satisfactory level of rust resistance associated with good grain appearance; however, it is important to continue assessing the disease severity in future cycles, because the resistance of the population might be broken by new races of the pathogen. The genetic gain for rust resistance in common bean with recurrent selection was confirmed (Menezes Junior et al. 2013). Therefore, recurrent selection is an efficient breeding strategy, in case the population resistance is broken, since new sources of disease resistance can be inserted during the phases of recombination.

For angular leaf spot, the disease severity increased $14.3 \%$ more in the $\mathrm{C}_{\mathrm{I}}$ than the $\mathrm{C}_{0}$ families during the rainy season. Nevertheless, the mean disease severity in the two cycles allowed the classification as moderately resistant. It is worth remembering that the higher the severity grade, the more susceptible is the genotype. Arantes et al. (2010)

Table 7. Means of grain yield ( $\mathrm{kg} / \mathrm{ha}$ ). plant architecture. grain appearance and rust severity (RU) and of angular leaf spot (LS). in the simultaneous evaluation of the families in $\mathrm{C}_{0}$ and $\mathrm{C}_{\mathrm{I}}$ and estimates of genetic gain $(\mathrm{GG})$. based on the separate analyses (winter and rainy seasons 2011 ) and combined analysis

\begin{tabular}{|c|c|c|c|c|c|}
\hline & Grain yield & Plant architecture & Grain appearance & Severity of RU & Severity of LS \\
\hline & \multicolumn{5}{|c|}{ Winter season 2011} \\
\hline $\mathrm{C}_{0}$ & 4157 & 2.4 & 2.2 & 2.3 & 1.3 \\
\hline $\mathrm{C}_{\mathrm{I}}$ & 4532 & 2.4 & 2.2 & 2.3 & 1.3 \\
\hline \multirow[t]{2}{*}{$\mathrm{GG}(\%)$} & 9.0 & 0 & 0 & 0 & 0 \\
\hline & \multicolumn{5}{|c|}{ Rainy season 2011} \\
\hline $\mathrm{C}_{0}$ & 2651 & 2.6 & - & 1.3 & 3.5 \\
\hline $\mathrm{GG}(\%)$ & \multicolumn{5}{|c|}{ Combined } \\
\hline $\mathrm{C}_{0}$ & 3404 & 2.5 & - & 1.8 & 2.4 \\
\hline $\mathrm{C}_{\mathrm{I}}$ & 3697 & 2.5 & - & 1.8 & 2.6 \\
\hline $\mathrm{GG}(\%)$ & 8.6 & 0 & - & 0 & 8.3 \\
\hline
\end{tabular}


evaluated the genetic gain for resistance to angular leaf spot in common bean and found indirect gain for grain yield and grain type after eight selection cycles $(2.3 \%$ for yield and $2.5 \%$ for grain appearance).

In view of the absence of gain for resistance to angular leaf spot, some alternatives are possible for the following selection cycle. One possibility is to increase the selection pressure for disease resistance or another to include new lines as resistance source in the recombination phase, to increase the population variability. The possibility of introducing new parents during the recombination phases is one of the advantages of recurrent selection (Geraldi 1997, Ramalho et al. 2001), making the process much more dynamic. This strategy was successfully applied (Ramalho et al. 2005, Menezes Júnior et al. 2013).

Genetic gain in common bean breeding for disease resistance was also reported in some studies (Parrella et al. 2008, Arantes et al. 2010). Parrela et al. (2008) were successful in breeding families that combine anthracnose resistance, high yield, erect plants and good bean appearance.
Considering the four families with pyramided resistance to anthracnose, the indirect gains for yield, plant architecture and grain appearance were, respectively, 3.33\%, 4.14\% and $0.31 \%$.

Recurrent selection was efficient in carioca bean breeding, since a genetic gain in grain yield of $8.6 \%$ was observed after two selection cycles. In addition, families with the potential to generate superior lines to Pérola, BRSMG Majestoso and BRSMG Madrepérola were identified. The presence of variability in the population, for all traits, shows the possibility of successful selection in the subsequent cycles and that the program of recurrent selection ought to be continued.

\section{ACKNOWLEDGEMENTS}

The authors thank the Brazilian Council for Scientific and Technological Development (CNPq), Coordination for the Improvement of Higher Education Personnel (CAPES) and Fundação de Amparo à Pesquisa do Estado de Minas Gerais - FAPEMIG for the support of this research

\section{Progresso genético e potencial de famílias de feijão carioca obtidas por meio de seleção recorrente}

Resumo - O objetivo deste trabalho foi estimar o progresso genético de dois ciclos de seleção recorrente no melhoramento de feijão carioca e identificar famílias com potencial para gerar linhagens superiores. A população base, ciclo zero $\left(C_{0}\right)$, foi obtida pela combinação de 20 genitores de grãos tipo carioca, portadores de fenótipos favoráveis para vários caracteres de interesse agronômico. Os genitores foram recombinados em esquema de dialelo circulante, com cada genitor participando de dois cruzamentos, gerando 20 populações. Dessas populações, foram derivadas as famílias e avaliadas por três safras, nas gerações $F_{2 \cdot 3^{\prime}}, F_{2 \cdot 4}$ e $F_{2 \cdot 5^{\circ}}$ Os mesmos procedimentos de recombinação e avaliação do $C_{0}$ foram realizados no ciclo um $\left(C_{p}\right)$. O progresso genético para produtividade, estimado com base na avaliação simultânea das 40 melhores famílias de cada ciclo, foi de 8,6\%. Foram identificadas famílias com potencial para gerar linhagens superiores à cultivar Pérola, especialmente entre as famílias do $C_{r}$

Palavras-chave: Phaseolus vulgaris, ganho genético, melhoramento de feijoeiro.

\section{REFERENCES}

Arantes LO, Abreu AFB and Ramalho MAP (2010) Eight cycles of recurrent selection for resistance to angular leaf spot in common bean. Crop Breeding and Applied Biotechnology 10: 232-237.

Carneiro JES, Ramalho MAP, Abreu AFB and Gonçalves FMA (2002) Breeding potential of single, double and multiple crosses in common bean. Crop Breeding and Applied Biotechnology 2: 515-524.

Collicchio E, Ramalho MAP and Abreu AFB (1997) Associação entre o porte da planta do feijoeiro e o tamanho dos grãos. Pesquisa Agropecuária Brasileira 32: 297-304.

Couto MA, Santos JB and Ferreira JL (2008) Melhoramento do feijoeiro comum com grão tipo carioca, visando resistência à antracnose e à mancha-angular. Ciência e Agrotecnologia 32: 1643-1648.

Cruz CD (2013) GENES - a software package for analysis in experimental statistics and quantitative genetics. Acta Scientiarum 35: 271-276.

Garcia RE, Robinson RA, Aguilar JAP, Sandoval SS and Guzman RP (2003) Recurrent selection for quantitative resistance to soil borne diseases in beans in the Mixteca region, México. Euphytica 130: 241-247.

Geraldi IO (1997) Selección recurrente en el mejoramiento de plantas. In Guimarães EP (ed) Selección recurrente en arroz. CIAT, Cali, p. 3-11.

Menezes Júnior JAN, Ramalho MAP and Abreu AFB (2008) Seleção recorrente para três caracteres do feijoeiro. Bragantia 67: 833-838.

Menezes Júnior JAN, Rezende Júnior LS, Rocha GS, Silva VMP, Pereira, AC, Carneiro PCS, Peternelli LA and Carneiro JES (2013) Two cycles of recurrent selection in red bean breeding. Crop Breeding and Applied Biotechnology 13: 41-48. 
AF Alves et al.

Parrela NNLD, Santos JB and Parrella RAC (2008) Seleção de famílias com resistência à antracnose, produtividade e tipo de grão carioca. Ciência e agrotecnologia 32: 1503-1509.

Ramalho MAP, Pirola LH and Abreu AFB (1998) Alternativas na seleção de plantas de feijoeiro com porte ereto e grão tipo carioca. Pesquisa Agropecuária Brasileira 33: 1989-1994.

Ramalho MAP, Abreu AFB and Santos JB (2001) Melhoramento de espécies autógamas. In Nass L L, Valois ACC, Melo IS and ValadaresInglis M C (eds) Recursos genéticos e melhoramento de plantas. Fundação MT, Rondonópolis, p. 201-230.

Ramalho MAP, Abreu AFB and Santos JB (2005) Genetic progress after four cycles of recurrent selection for yield and grain traits in common bean. Euphytica 144: 23-29.

Ranalli P (1996) Phenotypic recurrent selection in common bean (Phaseolus vulgaris L.) based on performance of $\mathrm{S}_{2}$ progenies. Euphytica 87: 127-132.

Rocha GS, Pereira LPL, Carneiro, PCS, Paula Júnior, TJ and Carneiro
JES (2012) Common bean breeding for resistance to anthracnose and angular leaf spot assisted by SCAR molecular markers. Crop Breeding and Applied Biotechnology 12: 34-42.

Silva GS, Ramalho MAP, Abreu AFB and Nunes JAR (2010) Estimation of genetic progress after eight cycles of recurrent selection for common bean yield. Crop Breeding and Applied Biotecnology 10: 351-356.

Singh SP, Terán H, Muñoz CG and Takegami JC (1999) Two cycles of recurrent selection for seed yield in common bean. Crop Science 39: 391-397.

Souza TLO, Alzate-Marin AL, Moreira MA and Barros EG (2005) Análise comparativa da variabilidade patogênica de Uromyces appendiculatus em algumas regiões brasileiras. Fitopatologia Brasileira 30: 143-149.

Stavely JR, Freytag GF, Steadman JR and Schwartz HF (1983) The Bean rust workshop. Anual Report of the Bean Improvement Cooperative 26: 4-6.

Van Schoonhoven A and Pastor-Corrales MA (1987) Standard system for the evaluation of bean germplasm. CIAT, Cali, 54p. 